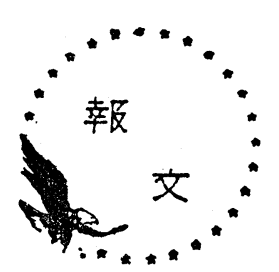

\section{成形コークスの製造と高炉装入試験}

一昭和 47 年 4 月 20 日講演一

\author{
住友金属工業株式会社 菅沢清志 - 仁礼尚道 \\ 田坂鋼二・角南好彦 \\ 京阪煉炭工業株式会社 日野契芳 - 坂井武雄 \\ 安部信義・篠田正隆
}

\section{1. 緒言}

強粘結炭を使用しないで, 非粘結炭を主原料とした 高炉用成形コークス製造に関する研究は, 十数年前か ら，わが国をはじめ世界各国で行なわれてきた。そし て2，3の国では，試作された成形コークスが，700 $\mathrm{m}^{3}$ 程度の小型高炉において試験的に使用されたこと もあるが，試験期間が短かったことや，ダストの増 加, 風圧の上昇などが認められたことなどから, 成形 コークスが大型高炉に使用できるか否かは疑問で亦っ た。

京阪煉炭工業（株）で注, 長年の経験によって得た 石炭成形技術を治金用コークスの製造に応用すべく， 昭和31年から研究を進め, 昭和44年にいたり, 大阪市 内北港地区にある同社の敷地内に約12億円の工費で, 中間規模の成形コークス製造設備の建設を開始した。 一方, 住友金属工業（株）ならびに住金化工（株） では, 将来の強粘結炭資源対策の一つとして, 成形コ 一クス法を重視し，昭和40年から，その製造方法につ いて調查研究を進め, 小型装置により実験的に良質な
成形コークスを製造しらる見通しを得たが，実験規模 を拡大寸るにあたり, 京阪煉炭工業（株）の石炭成形 技術に着目し, 昭和 45 年末から, 成形コークスの量産 およびその高炉使用について共同研究を行ならに至っ た。その結果, 良質の成形コークスが製造できること が確認されたので, 昭和46年11月から, 京阪煉炭工業

(株) 大阪コークス工場の操業を開始した。そして, 大阪コークス工場で生産された成形コークスは，住友 金属工業（株）小倉製鉄所第 2 高炉に扔いて，昭和 46 年 12 月から試験的に装入を開始し, 昭和 47 年 3 月末現 在で50\%配合試験を終了した。この間の同高炉におけ る成形コークスの使用量は, 約 14, 000t 亿達し, 高炉 炉況・コークス比などの面で, 通常の高炉用コークス と比較して，なんらそん色なく使用できることが確認 された。

\section{2. 大阪コークス工場 (Photo 1) の概要}

所 在 地: 大阪市此花区北港本町 4 番地

工場敷地: 約 $31,000 \mathrm{~m}^{2}$

貯炭能力: 約 $20,000 t$

Table 1 Trials in industrial blast furnaces of formed coke

\begin{tabular}{|c|c|c|c|c|}
\hline Company and Works & State & Blast furnace & Test period & Used coke \\
\hline Petrovskii Works ${ }^{2)}$ & U.S.S.R. & $700 \mathrm{~m}^{3}$ (vol.) & $\begin{array}{l}\text { Oct. } 29-\text { Nov. } 6 \\
1966 \text { days }\end{array}$ & $\begin{array}{l}\text { UKHIN. } \quad 25 \% \\
3,000 \mathrm{t}\end{array}$ \\
\hline $\begin{array}{l}\text { Armco Steel } \\
\text { Hamilton Works }{ }^{1)}\end{array}$ & U.S.A. & $\begin{array}{l}5.6 \mathrm{~m}^{\text {(h. d. })} \\
641 \mathrm{~m}^{3} \text { (vol.) }\end{array}$ & $\begin{array}{l}1967 \\
12 \text { days }\end{array}$ & $\begin{array}{l}\text { F. M. C. } \\
\quad 10,000 \mathrm{t}\end{array}$ \\
\hline $\begin{array}{l}\text { Hoesch AG } \\
\text { Huttenwerke, Dortmund }{ }^{1)}\end{array}$ & $\begin{array}{l}\text { West } \\
\text { Germany }\end{array}$ & $\begin{array}{l}9.5 \mathrm{~m} \text { (h. d.) } \\
1438 \mathrm{~m}^{3} \text { (vol.) }\end{array}$ & $\begin{array}{l}\text { Mar. 28, } 1969 \\
\quad 1 \text { days }\end{array}$ & $\begin{array}{l}\text { B. F. } \\
\quad 1,500 t\end{array}$ \\
\hline $\begin{array}{l}\text { Reinstahl Huttenwerke }{ }^{3)} \mathrm{AG} \\
\text { Werk Henrichshutte, } \\
\text { Hattingen }\end{array}$ & $\begin{array}{l}\text { West } \\
\text { Germany }\end{array}$ & $\begin{array}{l}6.8 \mathrm{~m} \text { (h. d.) } \\
764 \mathrm{~m}^{3} \text { (vol.) }\end{array}$ & $\begin{array}{l}\text { Apr. } 3,1970 \\
7 \text { days }\end{array}$ & $\begin{array}{l}\text { B. F. } 100 \% \\
7,000 t\end{array}$ \\
\hline $\begin{array}{l}\text { Inland Steel } \\
\text { Indiana Harbor Works }{ }^{1)}\end{array}$ & U.S. A. & - & $\begin{array}{c}\text { Aug. 25, } 1970 \\
1 \text { days }\end{array}$ & $\begin{array}{c}\text { F. M.C. } \\
140 \mathrm{t}\end{array}$ \\
\hline $\begin{array}{l}\text { Sumitomo Metal } \\
\text { Industries. Ltd. } \\
\text { Kokura Works }\end{array}$ & Japan & $\begin{array}{l}8.4 \mathrm{~m} \text { (h. d.) } \\
1350 \mathrm{~m}^{3} \text { (vol.) }\end{array}$ & $\begin{array}{l}\text { Dec. } 10,1971 \sim \\
\text { Mar. 25, } 1972 \\
57 \text { days }\end{array}$ & $\begin{array}{l}\text { Keihan } \\
14,000 \mathrm{t}\end{array}$ \\
\hline
\end{tabular}




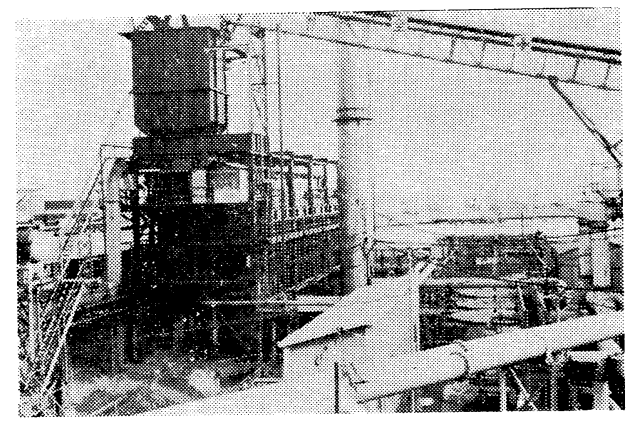

Photo. 1 A view of Osaka Coke Factory

配 合 設 備: 原料槽, 石炭粉砕機, 混炭機, 混練機 成 形 機: ダブルロール式 $15 \mathrm{t} / \mathrm{hr} 2$ 台 成形能力: $5,000 \mathrm{t} \sim 6,000 \mathrm{t} /$ 月

成形炭槽: 地上槽 (300t), 炉上槽 (40t) コークス炉 : DIDIER-KELLOGG 社製開底式竪型 炉 24 門 (6 門 $\times 4$ 組)

炭化室高さ $5.04 \mathrm{~m}$, 長さ $3.05 \mathrm{~m}$, 幅 $0.27 \mathrm{~m}$, 上下方向テーパー $100 \mathrm{~m} \mathrm{~m}$ 有効内容積 $3.9 \mathrm{t} /$ 門

成形炭装入量 $2.8 \sim 2.9 \mathrm{t} /$ 門

炉付帯設備: 消火車, コークワーフ, コークス篩

ガ ス 処 理 : 湿式および乾式脱硫装置, ガスホルダ

排水処 理 : 活性污泥法

\section{3. 成形炭の製造}

成形炭の性質は, 成形コークスの品質を決定する重 要な要素である。各原料の配合割合は, 使用する各石 炭のコークス化性を考慮して決定されるが，今回の試 験においては Table 2 に示すような配合を採用した。 成形炭の製造工程は, Fig. 1 に示すとおりである。 すなわち，原料槽から所定の配合割合にしたがって切 り出された各原料は， $3 \mathrm{~mm}$ 以下に粉砕されたのち, 混炭機をへて混練機に供給される。混練機内では，機 内に吹き込まれる高温水蒸気の熱によって, 配合原料 中のピッチが溶融するとともに，配合原料はさらに十 分な混練がなされたのち成形機に供給され加圧成形さ れる。

\section{Table 2 Raw materials of briquette coal}

Coking coal $5 \sim 10 \%$

Non coking coal $70 \sim 85 \%$

Carbon materials $0 \sim 10 \%$

Binders 10\%
(Bituminous coal)

(Anthracite,

Sub-bituminous coal) (Coke breeze, Oil coke)

(Coal tar, Hard pich)

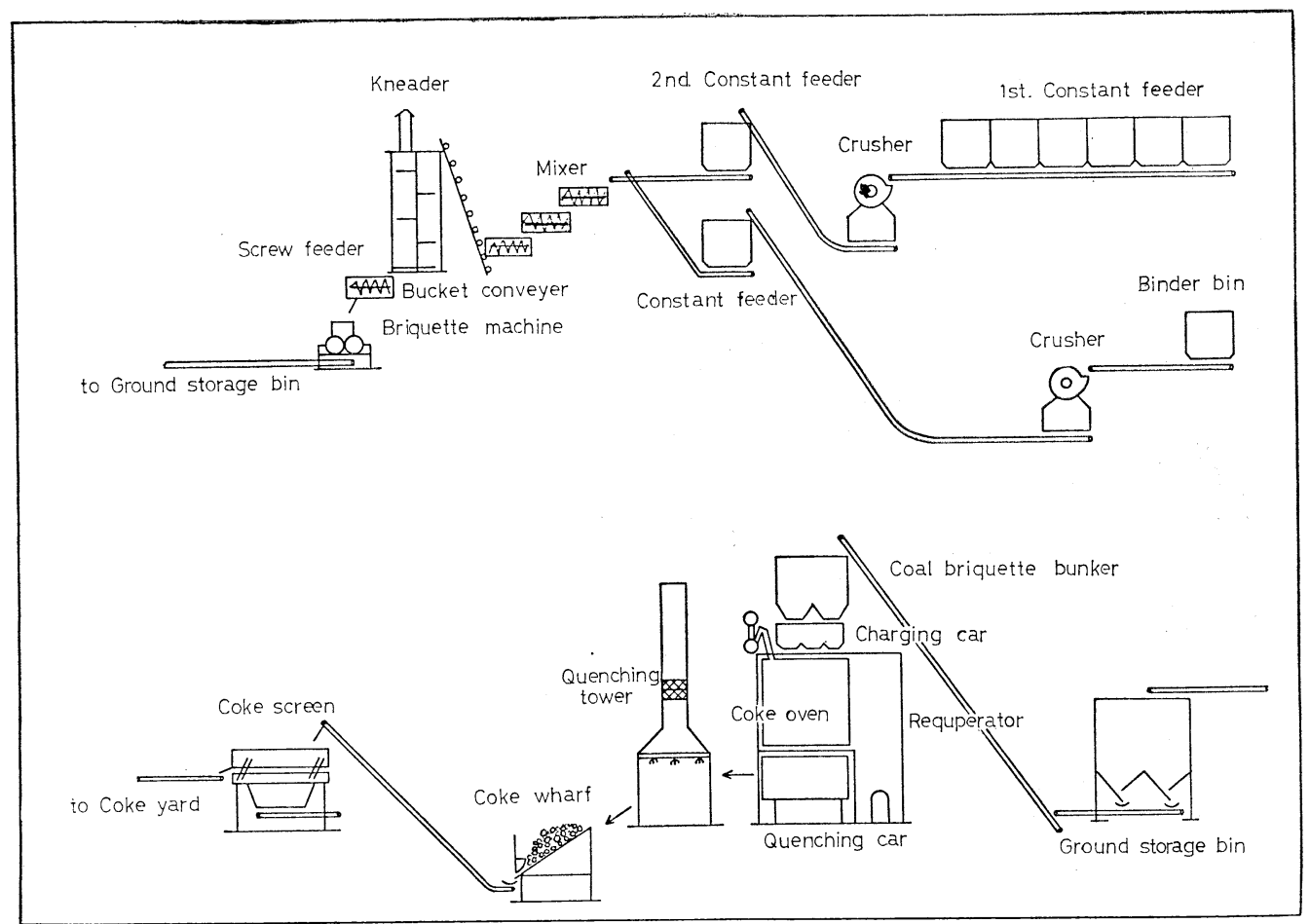

Fig. 1 Production process of formed coke 
Table 3 Quality of briquette coal

Total moisture $\quad 8 \sim 10 \%$

Ash

$7 \sim 9 \%$ (Dry basis)

Volatile matter

$22 \sim 29 \%$ (Dry basis)

Total sulphur

$0.4 \sim 0.6 \%$ (Dry basis)

Crushing strength

Average size

$>350 \mathrm{~kg} / \mathrm{p}$

Average weight

$53 \times 53 \times 35 \mathrm{~mm}$ (Masec type)

$65 \sim 66 \mathrm{gr} / \mathrm{p}$ (wet basis)

このようにして製造された成形炭は，ネットコンベ アおよびベルトコンベアにより地上槽にいったん貯蔵 される。成形炭の品質は Table 3 に示したとおりで ある。

\section{4. 成形炭の乾留}

西独 DIDIER-KELLOGG 社製の開底式䇾型コー クス炉は，Fig. 2 に示すような特殊な構造を有して いる。すなおち，炭化室の下方に開開可能な扉炎有 し, 被乾留物は乾留終了後, この屝を開放することに よって自重で炉外に排出されるので, 通常の室炉式二 一クス炉にみられるよらな押出機やガイド車などの重 機械類を必要としない。また加熱が水平フリュー方式 であること，および，燃焼用空気と燃焼排ガスとの熱 交換が，レキュペレーターによっていることも室炉式 コークス炉と異なるところである。

成形炭は, 炉上槽および装入車をへて, 炭化室上部 の装入口から炉内に装入されるが，この間の作業は， 通常のコークス炉作業となんら変りない。乾留終了後 の赤熱コークスは, 消火車により消火塔へ運ばれ, 散

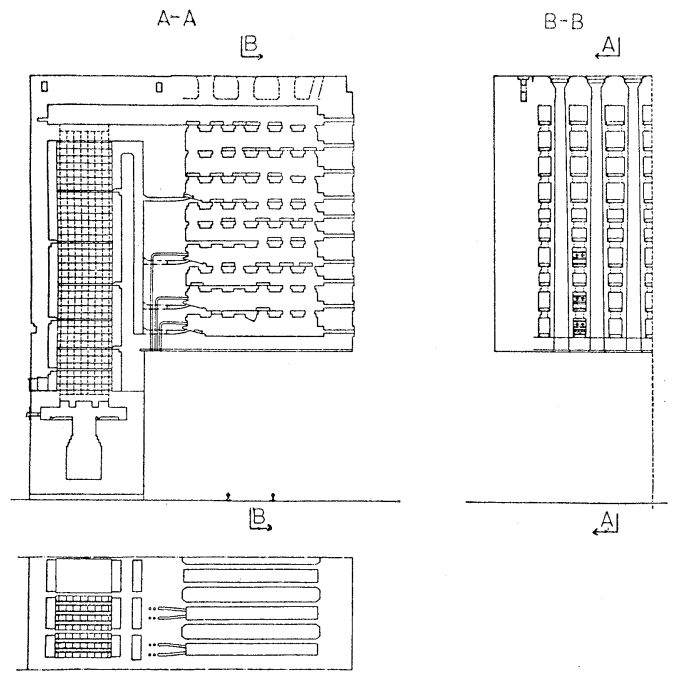

Fig. 2 Sketch of coke oven

Table 4 Operating indices of coke oven

Briquette coal production

Formed coke production

Oven charge

Oven output

Coke yield

Ratio of irregular sized coke $(+50 \mathrm{~mm})$

Ratio of coke breeze $(-15 \mathrm{~mm})$

Coking time

Flue temperature

Exhaust gas temperature

Heat consumption

By products

Crude Tar

Crude Gas

Content in coke oven gas

$\mathrm{CO}_{2}$

$\mathrm{O}_{2}$

$\mathrm{CO}$

$\mathrm{N}_{2}$

$\mathrm{CH}_{4}$

$\mathrm{H}_{2}$

$\mathrm{CnHm}$

Cal.
$4,503 \sim 5,000 \mathrm{t} / \mathrm{m}$

$3,500 \sim 4,000 \quad$ "

$2.8 \sim 2.9 \mathrm{t} /$ oven

$2.0 \sim 2.5 \quad$ "

$75 \sim 77 \%$

$<1.0 \%$

$<3.0 \%$

10. $0 \mathrm{hr}$

$1250 \sim 1300^{\circ} \mathrm{C}$

$350 \sim 400^{\circ} \mathrm{C}$

$620 \sim 650 \mathrm{kcal} / \mathrm{kg} \mathrm{coal}$

$45 \sim 50 \mathrm{~kg} / \mathrm{coal}$

$240 \sim 260 \mathrm{Nm}^{3} / \mathrm{coal}$
$1.6 \%$
$0.1 \%$
$6.4 \%$
4. $7 \%$
$22.0 \%$
$62.7 \%$
$2.5 \%$
$4,600 \sim 4,700 \mathrm{kcal} / \mathrm{Nm}^{3}$

Table 5 Comparison of quality between formed coke and conventional coke

Proximate and ultimate analysis (\%):

Total moisture

Ash (dry basis)

Volatile matter

$$
\text { (dry basis) }
$$

Total sulphur (dry basis)

Mechanical strength :

DI-15 (30R) by JIS

DI-15 (150R) by JIS

TI-6 (1400R) by ASTM

TI-6 (400R) at $1000^{\circ} \mathrm{C}$

Crushing st. in piece

Size analysis (\%):

$$
\begin{aligned}
& >50 \mathrm{~mm} \\
& 50-25 \\
& 25-15 \\
& <15
\end{aligned}
$$

Average

Average porosity (\%):

Water percent after 24

hours in water:

Bulk density $\left(\mathrm{gr} / \mathrm{cm}^{3}\right)$ :

Reactivity (\%) :

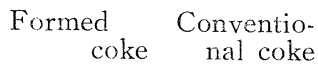

$\begin{array}{ccr}1 \sim 3 & 2 \sim 4 \\ 9.5 \sim 10.3 & 10 \sim 11 \\ 0.6 \sim 1.0 & 0.7 \sim 1.0\end{array}$

$0.49 \sim 0.53 \quad 0.58 \sim 0.65$

94. $0 \sim 96.0 \quad 91.8 \sim 92.5$

$83.5 \sim 87.0 \quad 79.0 \sim 82.0$

$69.0 \sim 75.0 \quad-$

$77.0 \sim 80.0 \quad 66.0 \sim 70.0$

$800 \mathrm{~kg} \quad 620 \mathrm{~kg}$

$\begin{array}{ccc}0 & 60 \sim 65 \\ 94 \sim 97 & 30 \sim 35 \\ 1 \sim 4 & 3 \sim 4 \\ 1 \sim 5 & 3 \sim 6 \\ 47 \times 47 \times 30 & 70 \\ 25 & 41\end{array}$

$\begin{array}{cc}8 & 17 \\ 1.24 & 1.13 \\ 7 \sim 8 & 6 \sim 7\end{array}$


水消火される。Table 4 亿最近のコークス炉作業実績 を示したが, 間接加熱であるため, 室炉と同じような 副産物が回収可能であることも, 本プロセスの一つの 特長である。

\section{5. 成形コークスの品質}

前述のような工程によって製造した成形コークスの 品質は, Table 5 に示したように, 普通の高炉用コー クスの品質と比較して, 同等もしくはそれ以上であ る。この成形コークスを高炉へ装入するに際し，われ われがとくに注意したのは, 成形コークスの熱間摩耗 強度と反応性の問題であった。

\section{5-1 熱間摩耗強度の測定}

コークスの熱間摩耗強度の測定装置は, 今回の試験 を始めるにあたり，住友金属工業（株）中央技術研究 所において，あらたに設計・製作したもので，装置の 概略は Fig. 3 に示すようなものである。すなわち, 回転炉は, 外径 $1.5 \mathrm{~m}$, 外幅 $1.06 \mathrm{~m}$, 内径 $1.05 \mathrm{~m}$, 内 幅 $0.60 \mathrm{~m}$ の大さのもので, 内部は八イアルミナレン ガ張りで，1 カ所にコークスかき上げ用の凸部（高さ $50 \mathrm{~mm}$ ) がある。炉内の加熱は, 水冷式バーナにより 行ない, 燃料には, プロパンまたはブタンを使用して いる。コークスの試験条件は, 次に示したとおりであ る。

温度 : $1,000^{\circ} \mathrm{C}$ (炉内壁面)

回 転 数 : 400 回転

回転速度: $6.25 \mathrm{rpm}$

炉内零囲気: $\mathrm{CO}_{2} 13 \sim 14 \%, \mathrm{CO} 1 \sim 2 \%, \mathrm{O}_{2} 0 \%$ 炉内压力: $+1 \sim 2 \mathrm{mmH}_{2} \mathrm{O}$

試料重量: $10 \mathrm{~kg}$

試 料粒 度 : 正常形のもの

5-2 反応性の測定

反応性の測定は，JIS-M 8713 に規定されている鉄 鉱石類の還元試験装置を用いた。すなわち, 内径 60

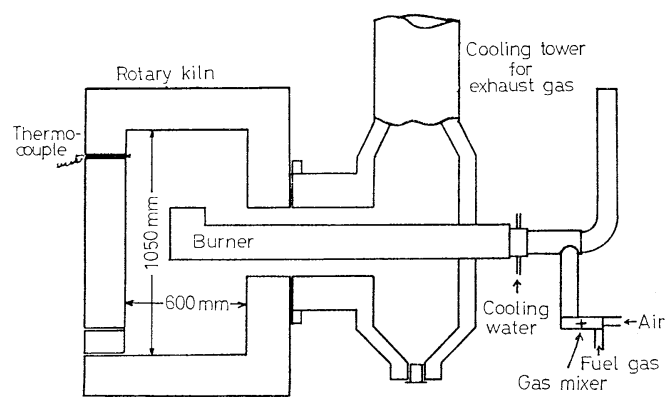

Fig. 3 Test equipment for coke strength at high temperature $\mathrm{mm}$, 長さ $600 \mathrm{~mm}$ のステンレス製反応管に成形コー クス 6 個を入れ， $950^{\circ} \mathrm{C}$ に昇温したのち，90分間 $5 l /$ min の流量で $\mathrm{CO}_{2}$ ガスを90分間反応管内に流したと きのコークスの重量隇少率をパーセントであらわした ものを反応性とした。したがって，JIS-K 2151 に規 定するコークスの反応性試験法による反応性指数と沬 表示法が若干異なっている。

\section{6. 高炉使用試験}

今回, われわれが製造した成形コークスの品質（と (汇熱間における摩耗強度) が, 通常の高炉用コーク スのそれよりも優れていることが確認されたので，昭 和46年11月下旬より, 京阪煉炭工業（株）大阪コーク ス工場から住友金属工業（株）小倉製鉄所への成形コ 一クスの輸送を開始した。そして, 同年12月10日から 同所第 2 高炉に拈いて, 成形コークスの装入を開始し た。小倉製鉄所第 2 高炉の概要および成形コークスの 使用経過は次に示すとおりである。

[第 2 高炉の概要]

火大れ: 昭和44年10月16日

総内容積: $1,350 \mathrm{~m}^{3}$

炉床 径: $8.4 \mathrm{~m}$

羽口数: 22 個

出銑口数: 2 個

装入方法: ベルトコンベア

炉頂圧力: $1.05 \mathrm{~kg} / \mathrm{cm}^{3}$

出銑能力: 最大 $3,000 \mathrm{t} /$ 日

〔成形コークス使用経過〕

第 1 期試験：昭和46年12月10日～12月22日 $7 \%$

第 2 期試験：昭和 47 年 1 月 3 日 1月15日 $10 \%$

第 3 期試験：昭和 47 年 1 月 22 日 2 月 4 日 $20 \%$

第 4 期試験：昭和 47 年 2 月10日 2月19日 $30 \%$

第 5 期試験：昭和 47 年 3 月 15 日 3 月 22 日 $40 \sim 50 \%$

第 1 期試験では, 成形コークスの配合率を $1 \%$ から $7 \%$ まで徐々に増加させ， ハンドリング上の問題およ び炉況への影響を調查したのち, 第 2 期以降の本格的 使用試験に移行した。

高炉操業成績の一例として, 成形コークス $30 \%$ 配合 および50\%配合の結果を Table 6 に示した。この間, 羽口破損や炉況の乱れによる減風・減鉱は全くなく, 操業はきわめて順調に推移した。Table 6 亿よると, いわゆる通気性指数 $(\Delta \mathrm{P} / \mathrm{V})$ は， $30 \%$ 配合・ $50 \%$ 配 合のそれぞれの期間で, 比較期間に比べ若干上昇して いるが, 一方, 炉況指数 (風圧指示曲線の軌跡総長さ を理想曲線の軌跡総長さで除した数值で, 小倉製鉄所 にて常用している指数である。本指数の大なるほど, 
Table 6 Operating indices of blast furnace

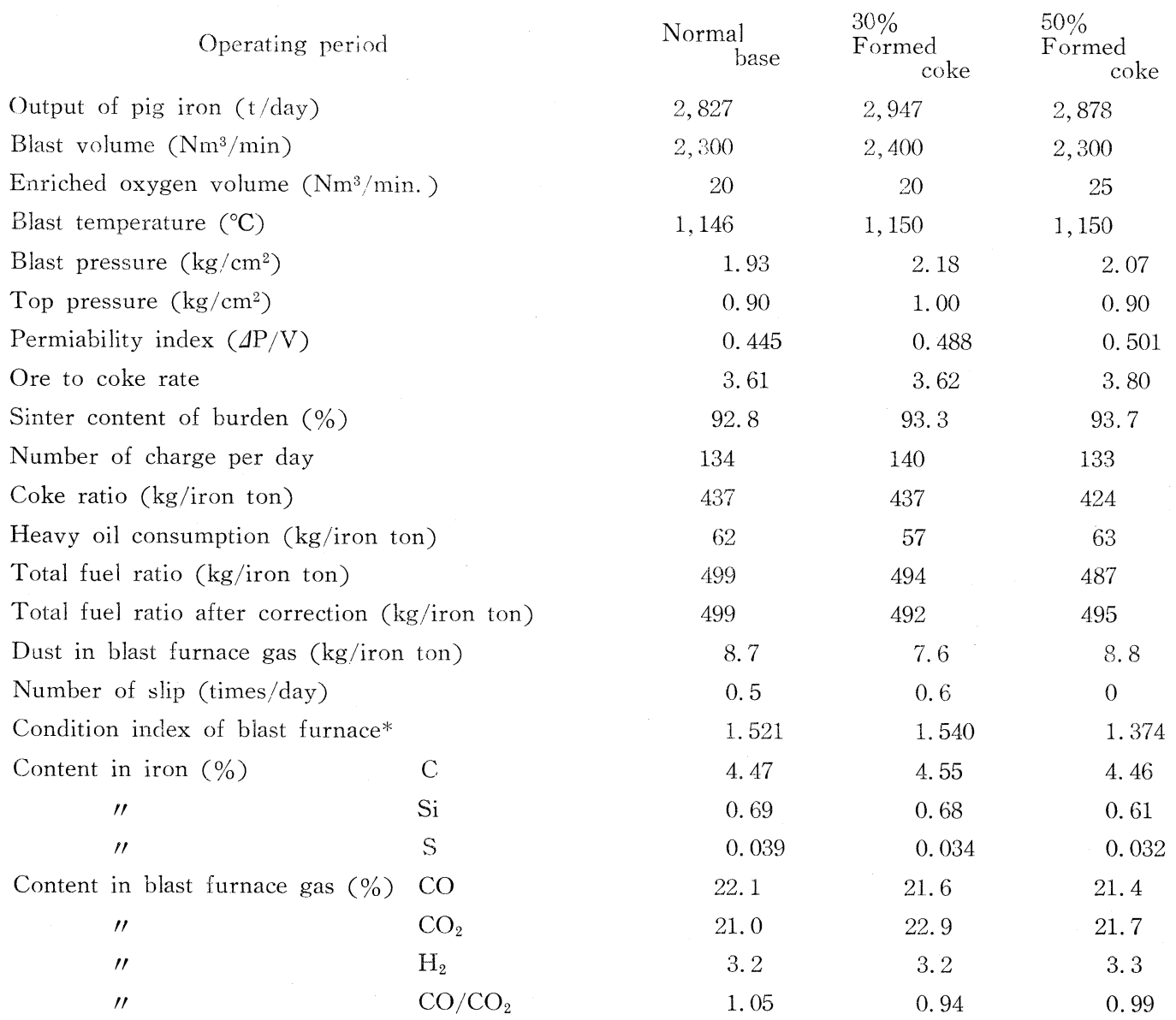

*Condition index : -

This index is the number divided TOTAL LENGTH of actual locus in blast pressure gauge by TOTAL LENGTH of ideal locus.

In the case that a fluctuation of blast pressure increase, this index becomes grow and grower, therefore, the condition of blast furnace became to deteriorate, it is explained.

炉内の風圧変動が大きく, 安定性を欠いていると解釈 できる）は，おのおのの期間汸扔いて，大きな変化は なく, 炉内の状況は, 全く安定していたことを示して いる。なお, 通気性指数の若干の上昇注, 今回の試験 に使用された成形コークスの粒度に関係があるものと 思われる。高炉ダストの発生量は, 全期間にわたり 7 9 kg/pt とほぼ一定であった。CO ガス利用率につ いては, 成形コークス $30 \%$ 配合の期間では, かなり向 上しているが, その他の期間では, $\mathrm{CO} / \mathrm{CO}_{2}$ は1.10 0.99の範囲内にあり, 大きな変化はなかったと判断し ている。コークス比や然料比へのコークスの反応性の 差の影響注ほとんど認められなかったが, Table 5 に
示すような反応性の差では, あまり問題にしなくても よい。

\section{7. 成形コークスの性状变化}

成形コークス $50 \%$ 使用試験後の定期休風時を利用し て, 羽口から成形コークスと通常コークスを取り出 し, その形状比較を行なった。羽口から取り出した成 形コークスは Photo. 2 に示すように，形は小さくな っているが，通常コークスとの区別が判別ができるほ ど本来の形状を保っていた。

Table 7 には, 羽口成形コークスの形状と重量の変 化を示したが，長さ方向の減少よりも，厚みの減少の ほうが大きくなっている。 


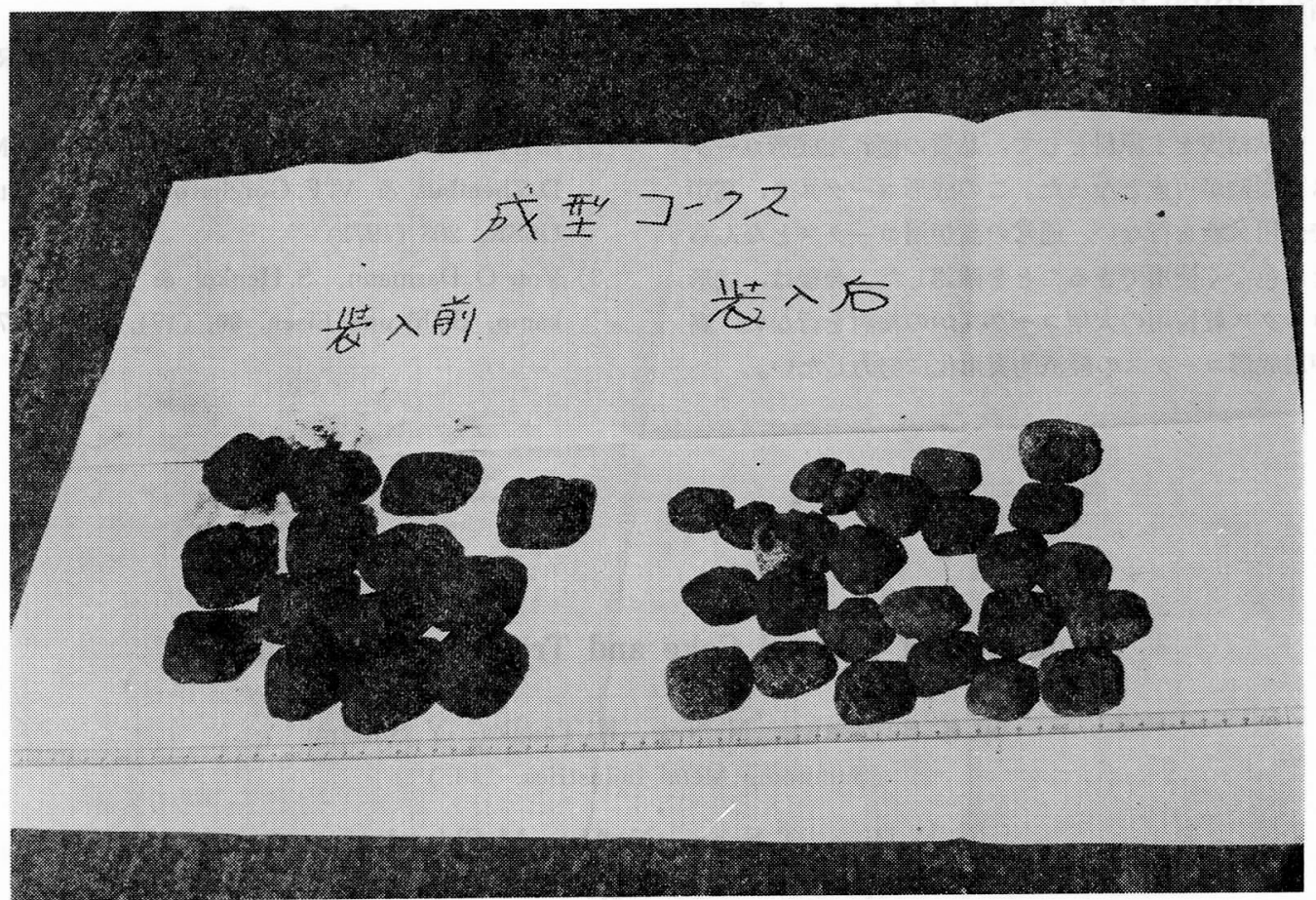

Right : from tuyere Left : before charging

Photo. 2 Formed coke samples

Table 7 Size transformation of fromed coke

$\begin{array}{llcc} & \begin{array}{l}\text { Before } \\ \text { charging }\end{array} & \begin{array}{c}\text { Sample } \\ \text { from } \\ \text { tuyere }\end{array} & \begin{array}{c}\text { Ratio of } \\ \text { decrease }\end{array} \\ \text { Thickeness } & 31.6 \mathrm{~mm} & 23.6 \mathrm{~mm} & 25.3 \% \\ \text { Length } & 46.5 \mathrm{~mm} & 37.2 \mathrm{~mm} & 20.0 \% \\ \text { Weight } & 46.9 \mathrm{gr} . & 22.5 \mathrm{~mm} & 52.0 \%\end{array}$

\section{Table 8 Transformation of crushing strength}

\begin{tabular}{|c|c|c|}
\hline & $\begin{array}{l}\text { Before charging } \\
(\mathrm{kg} / \mathrm{pc})\end{array}$ & $\begin{array}{l}\text { Sample from } \\
\text { tuyere }(\mathrm{kg} / \mathrm{pc})\end{array}$ \\
\hline $\begin{array}{c}\text { Conventional } \\
\text { coke }\end{array}$ & 620 & 302 \\
\hline Formed coke & 800 & 353 \\
\hline
\end{tabular}

また, Table 8 には, 圧潰強度の比較を示したが, このように, 羽ロレベルまで降下した時点でも, 成形 コークスの圧潰強度は, 通常のコークスのそれを上廻 っている。

従来, 主に外国で行なわれた成形コークスの高炉使 用試験結果を見ると, 風圧の著しい上昇・風圧変動の 増加・ダスト発生量の増加などが報告されているが, 今回の試験では, 外国の例にみられるようなトラブル
は全く認められず, 通常の高炉用コークスとなんら変 りなく使用できることが判明した。これは，われわれ が試験に用いた成形コークスの強度が, 通常のコーク スよりも高かったことや，反応性が大差なかったこと に主な原因があると考えられる。

なお, 成形コークス 100\% 操業試験については, 高 炉でのコークス消費量と成形コークスの生産量との間 に大きな差があったこと, および，100\% 操業を長期 閒続けるだけのコークスの貯蔵用地が確保できなかっ たことによって, 今回のわれわれの試験では, 断念せ ざるを得なかったが，30〜 50\%配合試験の結果から判 断して, 成形コークスの強度・粒度・反応性に留意す ることにより，十分実施可能であると信じている。

\section{8. 成形コークスの経済性}

現在の大阪コークス工場は, 中間規模的生産設備で あるため, 成形コークスの価格は, 直接・間接作業費 の面で, 通常の高炉用コークスの価格よりも割高であ るが, 炭化室の容積を拡大するとともに, ある生産量 以上の設備規模にすることによって, 製造コストを通 常のコークスなみに低減させることが可能であると考 えている。したがって現在, 京阪煉炭工業(株)では, 
西独 DIDIER-KELLOGG 社と協力して, 大型コー クス炉の開発検討を行なっている。

\section{9. 結 論}

非粘結炭を主原料として, 品質の優れた成形コーク スの製造が可能となった。この成形コークスを，高炉 で使用試験を行ない，通常の高炉用コークスとなんら そん色なく使用できることを確認した。今後は, 成形 コークス乾留用の大型コークス炉の検討を行ない，高 炉用成形コークスの経済的実用化に努力したい。

\section{文献}

1) P. Foch, A. Report of "Centre d'Etudes et Recherches des Charbonnages de France"

2) Z. I. Nekrasov, K.I. Kotov, N. A. Gladkov, M. D. Zhembus \& V.F. Gorcharov, Steel in the USSR, 263 (1971)

3) Von O.Darmann, S. Henkel \& K. D. Haverkamp, Stahl und Eisen, 90, (19), 1009 (1970)

\title{
Production of Formed Coke and Trials in Blast Furnace
}

\author{
by K.Sugasawa, N.Nire, K.Tasaka, Y.Sunami
}

(Sumitomo Metal Industries, Ltd.)

K.Hino, T.Sakai, N.Abe, M.Shinoda

(Keihan Rentan Kogyo Co., Ltd.)

SYNOPSIS : - The production of a formed coke in excellent quality has been realized in use of a non-coking coal as the main raw materials.

As the result of the experimental use of this formed coke for the No. 2 blast furnace in Kokura Steel Works of Sumitomo Metal Industries, Ltd.. it has been proved that it is not inferior to the conventional coke for same.

We intend to study for enlarging coke oven and to make efforts to materialize the economic rationalization of a formed coke for a large blast furnace. 